\title{
A Mediterranean perspective on European union and disunion: introduction
}

\author{
Ash Amin
}

\begin{abstract}
The Mediterranean is a region long marked by linguistic, literary, culinary, musical and intellectual traditions of Catholic, Arab, Jewish, Turkish and Latin cultures. It has existed as a mutable space of adjacent and overlapping cultural and historical currents, defying neat cartographic or civilisational delineations of national identity. The Mediterranean's place within Europe, and particularly European integration over the last half century, however, seems increasingly fragile, as a growing number of Mediterranean nations turn inwards, partly because of misgivings towards wider forms of membership and affiliation, despite the very many ways they are co-constituted. The articles in this issue consider the fractures of belonging in Europe and some ways of mending them by alerting us to the deep history of the Mediterranean as a meeting ground and crossing point between cultures.
\end{abstract}

Keywords: Integration, Europe, belonging.

Author: Ash Amin CBE FBA is Professor of Geography at the University of Cambridge, and former Foreign Secretary \& Vice-President of the British Academy. $\mathrm{He}$ is an expert in urban studies, globalisation, migrations and multiculturalism. Among his recent books are European Union and Disunion (2017, British Academy, with Philip Lewis), Seeing Like a City (2016, Polity, with Nigel Thrift), Releasing the Commons: Rethinking the Futures of the Commons (2016, Routledge, with Philip Howell), and Land of Strangers (2012, Polity).

(C) The author(s) 2020. This is an open access article licensed under a

Creative Commons Attribution-NonCommercial-NoDerivs 4.0 Unported License 
Just after the First World War, Paul Valéry offered a telling interpretation of how countries with very different legacies come together, observing that Europe was 'born from the exchange of material and spiritual matters, voluntary and involuntary cooperation between races as well as the concurrence of religions, systems and interests on a very limited territory'. ${ }^{1}$ Here, exchange, cooperation and co-presence emerge as the arbiters of difference, and if Valéry had the Mediterranean in mind, one can see precisely why, as it is a region marked by the linguistic, literary, culinary, musical and intellectual traditions of Catholic, Arab, Jewish, Turkish and Latin cultures. Then and now, as eloquently captured by Iain Chambers and Carme Colomina in this supplementary issue, the Mediterranean has existed as a mutable space of adjacent and overlapping cultural and historical currents, defying neat cartographic or civilisational delineations of national identity.

In many ways, Valéry's assumptions have lain at the heart of the project of European integration over the last half century, focusing on strengthening crosscountry interactions and common programmes. Yet, they seem increasingly fragile, as a growing number of Mediterranean nations turn inwards - against migration, each other, the European Union, liberal cosmopolitanism and the very idea of encounterdespite the very many ways in which they are co-constituted through the sutures of travel, trade, cultural exchange, common EU regulations and policies, shared culture, and transnational ownership and organisation. It seems the more that strains intensify on welfare and well-being in a country - for diverse reasons ranging from global economic slowdown and national austerity cuts, to cultural anxieties about immigration, globalisation, political abandonment and national identity-the worse gets discontentment with Europe, especially among those who are worst affected, regardless of the strength of the link between the symptoms and the workings of the EU. If Valéry identified exchange, cooperation and concurrence as the sources of unity in diversity, they seem now to be turning into reasons for disunity.

The aim of this issue is to make sense of the lines of fracture between nation and Europe in the Mediterranean by examining the circumstances contributing to disaffection. The contributions delve into the consequences of emotive populism, national cultural anxiety, eroding socio-economic prospects and political disillusionment. Thus, for example, Camil Ungureanu and Alexandra Popartan write of the combined effects of polarised and emotive public mobilisation, anxieties about immigration, the erosion of trust and the damaging consequences of austerity, resulting in the exacerbation of the inherent fragilities of democracy and equality, as detailed by Peter Wagner and Nadia Urbinati. These fragilities have been most acutely felt in the Southern European Union member states, as illustrated by Nick Malkoutzis for

\footnotetext{
${ }^{1}$ Valéry (1919).
} 
Greece, where the consequences of perceived EU restrictions have been severe.

The issue considers how the fractures of belonging in Europe could be healed, less by looking for the sources of unity in Europe imagined by Valéry, than by alerting us to the deep history of the Mediterranean as a meeting ground and crossing point between cultures, which could be mobilised through appropriate socio-economic and political reforms at national and EU level. The contributions reflect on the balances of contestation, solidarity and deliberation in selected countries so as to rethink democratic engagement in Europe as a form of expanding and overlapping participation across different spatial scales. In this kind of effort, some reconciliation is imagined between new forms of cosmopolitan belonging and traditional forms of national identity to avert the perils of populism, nationalism and inequality that have been so destructive in Europe's past.

For Jordi Vaquer, such reconciliation requires the repairs afforded by the social contract, environmental sustainability, renewed sovereignty and demographic stabilisation, all feeding into the tightening of liberal democratic overlaps and dependencies in Europe. If such are the macro-conditions of conviviality in Europe, they also require prosaic interventions affecting lived experience, as Tatiana Thieme, Ester Kovacs and Kavita Ramakrishnan argue, singling out cities as sites of refuge and hospitality for those in need of sanctuary, as the ground on which alternative humanitarian, economic and political experiments can take place outside traditional institutional structures.

The diagnoses and remedies offered in this short supplementary issue are far from exhaustive, but they are clear about the depth of reform-both redistributive and operative - required to reconcile nation to Europe and itself in a constitutively plural Mediterranean, before xenophobic nationalism throws Europe into chaos as it has so often in the past. A renewed politics of recognition, exchange and concurrence, before 'the city splits in two, before the last passage way (between the East and West) closes down, before hostages become an exchange currency ... before an enemy is discovered in the house next door, before this morning's friend becomes tonight's executioner'. ${ }^{2}$

This issue has emerged from an international symposium titled Europe: From Hope to Disaffection-A Mediterranean View, which the British Academy and the Centre de Cultura Contemporània de Barcelona (CCCB) convened on 2 July 2018. It forms part of a cycle of meetings and publications, led by the British Academy and sister academies across Europe on the topic of 'European Union and Disunion', seeking to understand mounting disaffection with the European Union.

\footnotetext{
${ }^{2}$ Chedid (1989).
} 
The views expressed in the issue are those of the authors alone, and not necessarily of the British Academy or CCCB, and are offered in the spirit of open reflection on the evolving and unsettled question of European affiliation.

\section{REFERENCES}

Chambers, Iain (2020), 'Thinking With the Diver: The Mediterranean in Historical Perspective', Journal of the British Academy, 8(s1): 5-12. https://doi.org/10.5871/jba/008s1.005

Chedid, Andrée (1989), The Return to Beirut, translated by R. Schwartz (London, Serpent's Tail).

Colomina, Carme, (2020), 'Rethinking Belonging: A Mediterranean Disaffection', Journal of the British Academy, 8(s1): 45-51. https://doi.org/10.5871/jba/008s1.045

Malkoutzis, Nick (2020), 'Greece as a Cautionary Tale, Not a Morality Play', Journal of the British Academy, 8(s1): 27-35. https://doi.org/10.5871/jba/008s1.027

Thieme, Tatiana, Kovacs, Eszter \& Ramakrishnan, Kavita (2020), 'Refugees as New Europeans, and the Fragile Line Between Crisis and Solidarity', Journal of the British Academy, 8(s1): 19-25. https://doi.org/10.5871/jba/008s1.019

Ungureanu, Camil \& Popartan, Alexandra (2020), 'Populism as Narrative, Myth Making and the "Logic" of Political Emotions', Journal of the British Academy, 8(s1): 37-43. https://doi.org/10.5871/jba/008s1.037

Urbinati, Nadia (2020), 'For a European Political Space', Journal of the British Academy, 8(s1): 13-17. https://doi.org/10.5871/jba/008s1.013

Valéry, Paul (1919), 'The Crisis of the Mind', The Athenaeum (London), 11 April; 2 May.

Vaquer, Jordi (2020), 'Democracies Under Stress', Journal of the British Academy, 8(s1): 63-69. https://doi.org/10.5871/jba/008s1.063

Wagner, Peter (2020),, 'Is There a Crisis of European Democracy? The Political Condition of Our Time', Journal of the British Academy, 8(s1): 53-61. https://doi.org/10.5871/jba/008s1.053

To cite the article: Ash Amin (2020), 'A Mediterranean perspective on European union and disunion: introduction', Journal of the British Academy, 8(s1): 1-4. DOI https://doi.org/10.5871/jba/008s1.001

Journal of the British Academy (ISSN 2052-7217) is published by

The British Academy, 10-11 Carlton House Terrace, London, SW1Y 5AH

www.thebritishacademy.ac.uk 